\title{
Enigmatic in vivo GlcNAc-1-phosphotransferase (GNPTG) transcript correction to wild type in two mucolipidosis III gamma siblings homozygous for nonsense mutations
}

\author{
Renata Voltolini Velho ${ }^{1,2}$, Nataniel Floriano Ludwig',3,4, Taciane Alegra ${ }^{2}$, Fernanda Sperb-Ludwig, ${ }^{1,3,4}$, \\ Nicole Ruas Guarany ${ }^{4}$, Ursula Matte $e^{1,2,5}$ and Ida VD Schwartz ${ }^{2,3,4,5}$
}

Mucolipidosis (ML) III gamma is a rare autosomal-recessive disorder caused by pathogenic mutations in the GNPTG gene. GNPTG encodes the $\gamma$-subunit of GIcNAc-1-phosphotransferase that catalyzes mannose 6-phosphate targeting signal synthesis on soluble lysosomal enzymes. ML III gamma patients are characterized by missorting of lysosomal enzymes. In this report, we describe the probable occurrence of mRNA editing in two ML III gamma patients. Patients A and B (siblings) presented at the adult age with a typical clinical picture of ML III gamma, mainly compromising bone and joints, and high levels of lysosomal enzymes in plasma and low levels in fibroblasts. Both were found to be homozygous for c.-112C $>G$ and c.328G $>T$ (p.Glu110Ter) mutations in genomic DNA (gDNA) analysis of GNPTG. Analysis of complementary DNA (cDNA), however, showed normal genotypes for both patients. Low GNPTG mRNA expression was observed in both patients. The mRNA editing can explain the differences found in patients $A$ and $B$ regarding gDNA and cDNA analysis, and the mild clinical phenotype associated with homozygosity for a nonsense mutation. Our results suggest that mRNA editing can be more frequent than expected in monogenic disorders and that GNPTG analysis should be performed on gDNA.

Journal of Human Genetics (2016) 61, 555-560; doi:10.1038/jhg.2016.13; published online 3 March 2016

\section{INTRODUCTION}

Lysosomes, first described by De Duve and collaborators ${ }^{1}$ in 1955 , are acidic organelles into which many types of macromolecules, including proteins, carbohydrates, nucleic acids and lipids, are delivered for degradation. The targeting of most lysosomal enzymes depends on mannose 6-phosphate residues that are recognized by mannose 6-phosphate-specific receptors mediating their transport to lysosomes. ${ }^{2,3}$ The key role in the formation of these residues is played by the Golgi-resident GlcNAc-1-phosphotransferase (EC 2.7.8.17) complex that is composed of three different subunits encoded by GNPTAB and GNPTG. ${ }^{3}$ GNPTAB (MIM\# 607840) located on chromosome 12q23.3, encodes the $\alpha$ - and $\beta$-subunits, whereas the $\gamma$-subunit is encoded by the gene GNPTG (MIM\# 607838), located on chromosome 16p13.3. ${ }^{4,5}$ GNPTG has 11 exons and spans $11.13 \mathrm{~kb}$.

Pathogenic mutations in GNPTG are associated with mucolipidosis (ML) type III gamma, formerly known as pseudo-Hurler polydystrophy (MIM\# 252600), a very rare autosomal-recessive disorder characterized by the abnormal trafficking and subcellular localization of lysosomal enzymes. There is not a frequent type of mutation in
GNPTG gene, and missense/nonsense/splice site mutations have already been described (Figure $1^{6}$ ). There are few reports about this disease, and all of the studies include a small number of patients. ${ }^{4,5}, 7-15$ The clinical manifestations include claw hand deformity, joint contractures, short stature and scoliosis. Mild coarsening of the face, astigmatism, mild retinopathy and cardiac valve involvement has also been reported. Moderate to severe dysostosis multiplex and Legg-Calvé-Perthes disease may be evident upon radiological examination. ${ }^{8,10}$ The need for prognostic information and genetic counseling has fueled the drive to establish genotype-phenotype associations in ML III gamma. However, close associations between mutant genotypes and clinical phenotypes have invariably been elusive, suggesting that other factors may be responsible for the clinical heterogeneity found in genetic diseases. ${ }^{16}$

Pre-mRNA processing and post-transcriptional modification can, together with mRNA decay, exert a profound influence on both the efficiency and fidelity of human gene expression. ${ }^{17-20}$ In addition, it has become increasingly clear that mRNA editing is a frequent phenomenon and may make a significant contribution to human

${ }^{1}$ Gene Therapy Center, Experimental Research Center, Hospital de Clínicas de Porto Alegre, Rua Ramiro Barcelos, Porto Alegre, RS, Brazil; ${ }^{2}$ Postgraduation Program on Genetics and Molecular Biology, Universidade Federal do Rio Grande do Sul, Avenida Bento Gonçalves, Porto Alegre, RS, Brazil; ${ }^{3}$ BRAIN Laboratory, Experimental Research Center, Hospital de Clínicas de Porto Alegre, Rua Ramiro Barcelos, Porto Alegre, RS, Brazil; ${ }^{4}$ Postgraduation Program in Medical Sciences, Universidade Federal do Rio Grande do Sul, Rua Ramiro Barcelos, Porto Alegre, RS, Brazil and ${ }^{5}$ Department of Genetics, Universidade Federal do Rio Grande do Sul, Avenida Bento Gonçalves, Porto Alegre, RS, Brazil Correspondence: Professor IVD Schwartz, Serviço de Genética Médica, Hospital de Clínicas de Porto Alegre, Rua Ramiro Barcelos, 2350, Porto Alegre, RS 90035-903, Brazil. E-mail: ischwartz@hcpa.edu.br

Received 2 July 2015; revised 20 January 2016; accepted 21 January 2016; published online 3 March 2016 


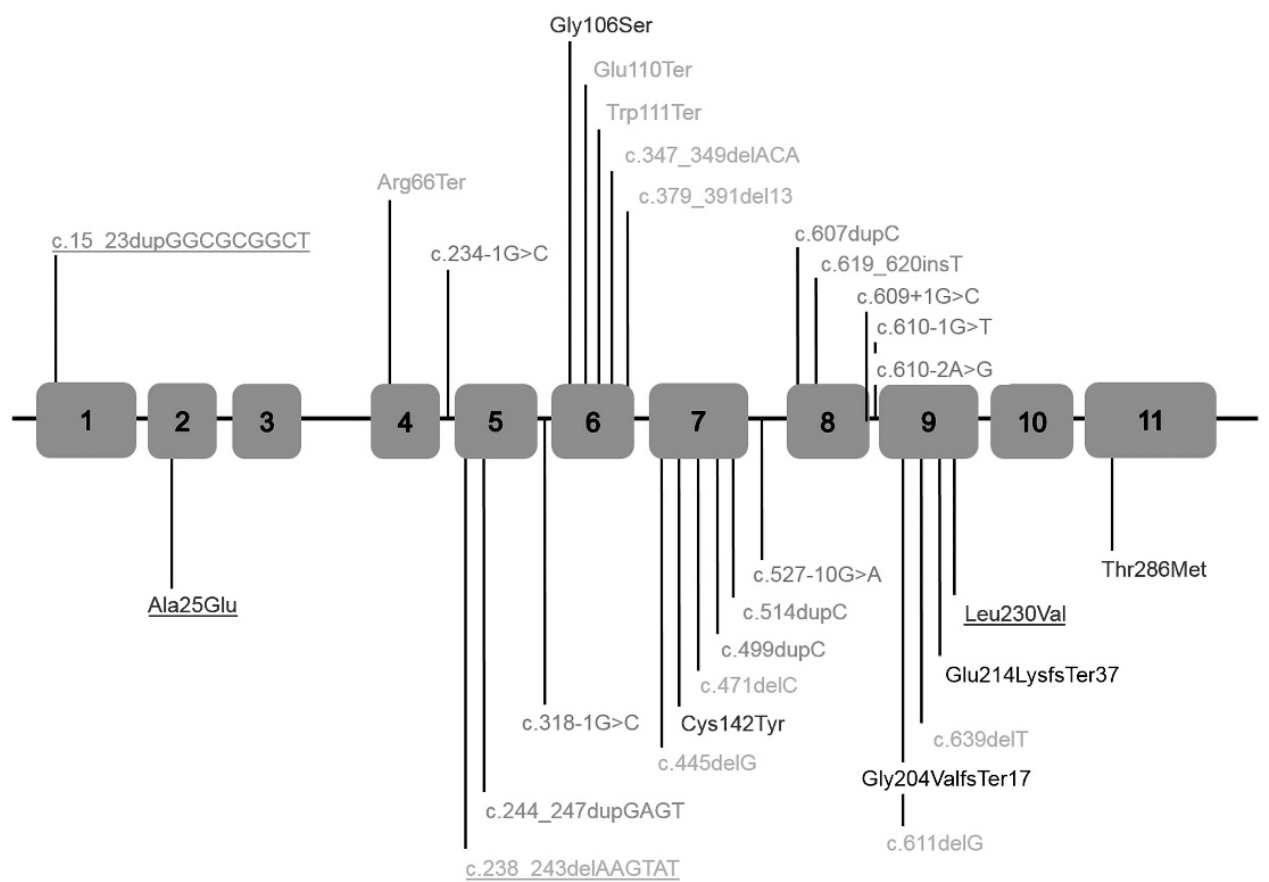

Figure 1 Schematic presentation of the pathogenic mutations described in GNPTG gene. The positions of missense (blue), nonsense (purple), insertions (red), deletions (green) and splicing mutations (brown) are represented. The underlined mutations are described for stuttering, not mucolipidosis (ML) III gamma. ${ }^{6} \mathrm{~A}$ full color version of this figure is available at the Journal of Human Genetics journal online.

transcriptome diversity. ${ }^{20,21}$ Since the original discovery of mRNA editing in trypanosomes nearly 30 years ago, ${ }^{22}$ mRNA editing has been found across all kingdoms of life, including plants, animals, fungi, protists, bacteria and viruses. ${ }^{23}$

The aim of this study is to report the probable occurrence of mRNA editing in ML III gamma disease.

\section{MATERIALS AND METHODS}

This study was approved by the institutional review board of HCPA (Hospital de Clínicas de Porto Alegre), Brazil. Two adult patients, who were siblings and presented with clinical and biochemical diagnoses of ML III, were enrolled.

\section{Clinical evaluation}

Clinical data were retrieved from medical files. Functional capacity was prospectively evaluated through the Functional Independence Measure (FIM) tool, always by the same examiner. The FIM is validated for the Brazilian population ${ }^{24,25}$ and evaluates functional capacity for self-care, sphincter control, mobility, communication and social integration. It consists of two subscores (mobility ranging from 13 to 91 points, and cognition ranging from 5 to 35 points). The total score ranges from 18 (worse) to 126 (better) points. Patient functionality is classified as follows: (1) complete dependence (total assistance) $=18$ points; (2) modified dependence (assistance in up to $50 \%$ of tasks) $=19-60$ points; (3) modified dependence (assistance in up to $25 \%$ of tasks $=61-103$ points; and (4) complete or modified independence $=104-126$ points.

Goniometry was used to evaluate the following joints for all possible passive movements: shoulder, elbow, wrist, hip, knee and ankle, ${ }^{26}$ always by the same examiner.

\section{GNPTG and GNPTAB analysis}

Genomic DNA (gDNA) was extracted using Easy-DNA Purification kit (Life Technologies, Carlsbad, CA, USA) from peripheral blood leukocytes (patients and their parents) and fibroblasts (patients). GNPTG and GNPTAB genes amplification was performed as described by Persichetti et al. ${ }^{10}$ and Cury et al., ${ }^{27}$ respectively. Total RNA was extracted from patient's cultured fibroblasts (patients) and blood samples (patients and the mother) using the RNeasy Mini Kit (Qiagen, Hilden, Germany). The same sample used for gDNA extraction was used for RNA extraction. Reverse transcriptase PCR (RT-PCR) amplification was performed using specific primers to amplify the c.328G $>$ T allele (forward 5'-AGTATGAGTTCTGCCCGTTCC-3' and reverse 5'-CAG GGTTGGGTACACTAGCAA- $3^{\prime}$ ). Samples were submitted to automated DNA sequencing performed on an ABI PRISM 3500 Genetic Analyzer (Applied Biosystems, Waltham, MA, USA). The sequences of the GNPTG and GNPTAB genes used as references were, respectively, GenBank accession nos. NG_016985.1 and NM_024312.3.

The presence of each mutation was always confirmed in two independent experimental assays and also in the patients' relatives. In addition, the c. $-112 \mathrm{C}>\mathrm{G}$ mutation was investigated in 200 control alleles from random samples of blood bank donors by DNA sequencing.

\section{Testing the authenticity of the GNPTG alleles and transcripts}

To exclude the possibility of artifactual nucleotide misincorporation during reverse transcription, all experiments were repeated twice using two different reverse transcriptases, a High Capacity cDNA Reverse Transcription Kit (Applied Biosystems) and SuperScript III (Life Technologies). To minimize the risk of eventual artifactual nucleotide misincorporation by DNA polymerase in vitro during PCR amplification, PCR was performed with two different polymerases, DreamTaq DNA Polymerase (Thermo Scientific, Waltham, MA, USA) and Phusion High-Fidelity DNA Polymerase (Thermo Scientific).

\section{Quantitative RT-PCR}

The GNPTAB and GNPTG mRNA levels were determined by quantitative RT-PCR using $2 \times$ SYBR Green PCR Master Mix (Applied Biosystems) with Mx3000P (Stratagene, La Jolla, CA, USA). GAPDH was chosen as a housekeeping gene. Primers and reaction conditions were determined based on Ho $e a_{\text {al. }}{ }^{28}$ The relative quantification of RNA was normalized to the level of GAPDH mRNA in the same complementary DNA (cDNA) using the comparative CT method $\left(2^{-\Delta \Delta C T}\right)$. 


\section{Restriction fragment length polymorphism analysis}

To investigate the presence of the wild and the mutant sequence in the mRNA obtained from fibroblasts of patients A and B, the region of interest (324 bp) was amplified. The mutation c.328G $>\mathrm{T}$ creates a restriction site for the Spel enzyme and the PCR fragment (324 bp) is cleaved in two fragments (215 and $109 \mathrm{bp}$ ). In this analysis, we used $0.3 \mathrm{U}$ of SpeI restriction enzyme (New England Biolabs, Ipswich, MA, USA), $2 \mu \mathrm{l}$ of $1 \times$ CutSmart Buffer (supplied with the restriction enzyme; New England Biolabs) and $17.7 \mu \mathrm{l}$ of amplicon; samples were incubated overnight at $37^{\circ} \mathrm{C}$.

\section{Copy number variation analysis}

Copy number variation analysis of the controls and patients $\mathrm{A}$ and $\mathrm{B}$ were performed in a quantitative PCR assay. The following reagents were used for amplification in $12 \mu \mathrm{l}: 2.5 \mu \mathrm{l}$ of DNA ( 40 ng), $0.5 \mathrm{pmol}^{-1} \mathrm{l}^{-1}$ of each primer, $6.25 \mu \mathrm{l}$ of $2 \times$ SYBR Green PCR Master Mix (Applied Biosystems) and final volume was adjusted with sterile water. GNPTG primers were designed to amplify exon 6 (forward 5'-TCTGGCACGAGTGGGAGAT-3' and reverse $5^{\prime}$-AACGGCAGGCGTCACC- $3^{\prime}$ ), where the p.Glu110Ter is located. RNase $P$ primers were already described by Szantai et al. ${ }^{29}$ and served as an internal standard (two copies). The strategy is based on the relative quantification of the target sequence (GNPTG) and a reference sequence (RNase $P)$ in the same

Table 1 Summary of clinical, functional and mobility characteristics of patients with mucolipidosis III gamma

\begin{tabular}{|c|c|c|c|}
\hline & Patient A & Patient B & $\begin{array}{c}\text { Reference } \\
\text { values }\end{array}$ \\
\hline Gender & M & M & \\
\hline $\begin{array}{l}\text { Parental } \\
\text { consanguinity }\end{array}$ & No & No & \\
\hline $\begin{array}{l}\text { Age at diagnosis } \\
\text { (years) }\end{array}$ & 34.7 & 40.0 & \\
\hline $\begin{array}{l}\text { Age at inclusion } \\
\text { (years) }\end{array}$ & 42.0 & 44.0 & \\
\hline Height (cm) & 148.0 & 152.0 & \\
\hline Height Z-score ${ }^{a}$ & -3.77 & -3.00 & \\
\hline $\begin{array}{l}\text { Education/ } \\
\text { Occupation }\end{array}$ & $\begin{array}{l}\text { Elementary school/ } \\
\text { farmer }\end{array}$ & $\begin{array}{l}\text { Elementary school/ } \\
\text { farmer }\end{array}$ & \\
\hline FIM total & 120 & 122 & $18-126^{b}$ \\
\hline FIM mobility & 85 & 87 & $13-91^{b}$ \\
\hline FIM cognitive & 35 & 35 & $5-35^{b}$ \\
\hline Shoulder abduction & 101 & 106 & $180^{\circ}$ \\
\hline Shoulder flexion & 126 & 137 & $180^{\circ}$ \\
\hline $\begin{array}{l}\text { Shoulder internal } \\
\text { rotation }\end{array}$ & 32 & 35 & $90^{\circ}$ \\
\hline $\begin{array}{l}\text { Shoulder external } \\
\text { rotation }\end{array}$ & 40 & 53 & $90^{\circ}$ \\
\hline Shoulder extension & 68 & 67 & $80^{\circ}$ \\
\hline Elbow extension & 49 & 39 & $0^{\circ}$ \\
\hline Elbow flexion & 121 & 126 & $160^{\circ}$ \\
\hline Wrist extension & 54 & 20 & $70^{\circ}$ \\
\hline Wrist flexion & 32 & 64 & $80^{\circ}$ \\
\hline Hip extension & 16 & 16 & $45^{\circ}$ \\
\hline Hip flexion & 99 & 70 & $125^{\circ}$ \\
\hline Hip abduction & 23 & 18 & $45^{\circ}$ \\
\hline Hip adduction & 24 & 22 & $30^{\circ}$ \\
\hline Hip internal rotation & 39 & 23 & $60^{\circ}$ \\
\hline Hip external rotation & 21 & 15 & $70^{\circ}$ \\
\hline Knee flexion & 126 & 130 & $130^{\circ}$ \\
\hline Knee extension & 10 & 11 & $0^{\circ}$ \\
\hline
\end{tabular}

Abbreviations: FIM, Functional Independence Measure; M, male.

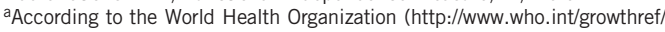

who2007_height_for_age/en/index.html).

bAs higher the values, as better.
DNA sample. Gene dosage analysis is calculated using the comparative CT method $\left(2 \times 2^{-\Delta \Delta C T}\right)$, where ${ }^{\Delta \Delta} \mathrm{Ct}=(\mathrm{Ct}$ RNase P control $-\mathrm{Ct}$ GNPTG 6 control) - (Ct RNase P sample-Ct GNPTG 6 sample). All the experiments were performed three times, and in each experiment the samples were analyzed in triplicate.

\section{Statistical analysis}

Values obtained for the relative quantification of GNPTAB and GNPTG mRNA in patients and controls samples were compared using Student's test (IBM SPSS Statistics version 20). The analysis of gene copy number was compared using analysis of variance (IBM SPSS Statistics version 20, Armonk, NY, USA). For both analyses, $P$-values of $<0.05$ were considered statistically significant.

\section{RESULTS}

\section{Clinical and biochemical evaluation}

A summary of the clinical, functional and mobility findings of the patients is presented in Table 1.

Patient A, male, is the third sibling from non-consanguineous parents. First symptoms started at the age of 10 years (claw hands). $\mathrm{He}$ developed disabling hip pain because of Legg-Calvé-Perthes disease, and prostheses were inserted bilaterally at 34 and 36 years of age. An umbilical hernia was repaired at the age of 37 years, and severe carpal tunnel syndrome was corrected by wrist surgery at the age of 40 years. At the last visit, he was 42 years old and currently working on the family farm, having no complaints or difficulties in his daily tasks. $\mathrm{He}$ did not finish high school but does not appear to have cognitive impairment. A physical exam showed mild coarse facial features, systolic murmur, no organomegaly, claw hands and severe joint contractures of the shoulders, elbows and knees. In addition to these symptoms, he had some difficulty in moving the right leg because of an external rotation of the knee. On echocardiography he had supravalvular aortic stenosis, minimal physiological mitral regurgitation, mild tricuspid regurgitation and systolic pulmonary artery pressure at $29 \mathrm{~mm} \mathrm{Hg}$, without other alterations. The neurological exam was normal. A polysomnography was performed and showed mild apnea hypopnea index (11.5).

Patient B, male, second sibling from non-consanguineous parents, was diagnosed at the age of 38 years, after the ML III diagnosis of his brother (patient A). Claw hands and shoulder contractures were noted since adolescence. He developed disabling hip pain because of Legg-Calvé-Perthes disease, and prostheses were inserted bilaterally at 38 and 40 years of age, respectively. At his last visit, he was 44 years old and currently working on the family farm, without complaints or difficulties in his tasks. Similar to his brother, he did not finish high school but does not appear to have cognitive impairment. A physical exam showed coarse facial features (even milder than patient A) and mild joint restrictions in the hands, elbow, shoulder and knees. The neurological exam was normal. The echocardiogram and polysomnography were normal.

The biochemical diagnosis of patients $\mathrm{A}$ and $\mathrm{B}$ were performed at the age of 34 and 40 years, respectively, by measuring the activities of lysosomal enzymes in plasma and in cultured fibroblasts. Both patients showed a marked increase of plasma lysosomal enzyme activities. In cultured fibroblasts of patients $\mathrm{A}$ and $\mathrm{B}$, the lysosomal enzyme activities were decreased in comparison with control fibroblasts (Table 2).

\section{GNPTG and GNPTAB mutations analysis}

Because the clinical and biochemical data suggested that the patients had ML III, genomic sequencing of GNPTG and GNPTAB was carried out. The GNPTG mutational profile was characterized 
Table 2 Mucolipidosis III gamma: biochemical characterization of patients included in this study

\begin{tabular}{|c|c|c|c|c|}
\hline Biochemical investigation & Sample & Patient A & Patient B & Reference values \\
\hline Arylsulfatase A & Plasma & + & + & - \\
\hline$\beta$-Glucuronidase & Plasma & 1037 & 1899 & $30-300 \mathrm{nmol} \mathrm{h}^{-1} \mathrm{ml}^{-1}$ \\
\hline Iduronate-sulfatase & Plasma & 1707 & 1644 & $122-463 \mathrm{nmol} 4 \mathrm{~h}^{-1} \mathrm{ml}^{-1}$ \\
\hline A-Mannosidase & Fibroblasts & 13 & NA & $60-400 \mathrm{nmol} \mathrm{h}^{-1} \mathrm{mg}^{-1}$ \\
\hline B-Galactosidase & Fibroblasts & 178 & 130 & $394-1440 \mathrm{nmol} \mathrm{h}^{-1} \mathrm{mg}^{-1}$ \\
\hline Iduronate-sulfatase & Fibroblasts & 12 & 4.8 & $35-80 \mathrm{nmol} 4 \mathrm{~h}^{-1} \mathrm{mg}^{-1}$ \\
\hline
\end{tabular}

Abbreviations: NA, not analyzed; +, present; -, absent;

Table 3 Mutations identified in Brazilian patients with mucolipidosis III gamma

\begin{tabular}{|c|c|c|c|}
\hline \multirow[b]{2}{*}{ Patient } & \multicolumn{2}{|c|}{$\begin{array}{l}\text { Pathogenic mutations } \\
\text { identified in GNPTG }\end{array}$} & \multirow{2}{*}{$\begin{array}{l}\text { Nonpathogenic mutations } \\
\text { identified in GNPTG }\end{array}$} \\
\hline & CDNA & Protein & \\
\hline Patient $A$ & $\begin{array}{l}\text { c. }[328 \mathrm{G}>\mathrm{T}] \\
{[328 \mathrm{G}>\mathrm{T}]}\end{array}$ & $\begin{array}{l}\text { p.[Glu110Ter]; } \\
\text { [Glu110Ter] }\end{array}$ & c. [-112C $>\mathrm{G}] ;[-112 \mathrm{C}>\mathrm{G}]$ \\
\hline Mother & c. [328G > T] & p.[Glu110Ter] & c. $[-112 \mathrm{C}>\mathrm{G}]$ \\
\hline Father & c. [328G > T] & p.[Glu110Ter] & c. $[-112 \mathrm{C}>\mathrm{G}]$ \\
\hline Patient B & $\begin{array}{l}\text { c. }[328 \mathrm{G}>\mathrm{T}] ; \\
{[328 \mathrm{G}>\mathrm{T}]}\end{array}$ & $\begin{array}{l}\text { p.[Glu110Ter]; } \\
\text { [Glu110Ter] }\end{array}$ & c. $[-112 \mathrm{C}>\mathrm{G}] ;[-112 \mathrm{C}>\mathrm{G}]$ \\
\hline Mother & c. $[328 \mathrm{G}>\mathrm{T}]$ & p.[Glu110Ter] & c. $[-112 \mathrm{C}>\mathrm{G}]$ \\
\hline Father & c. [328G > T] & p.[Glu110Ter] & c. $[-112 \mathrm{C}>\mathrm{G}]$ \\
\hline
\end{tabular}

by two mutations in homozygosis: c.328G $>\mathrm{T}$ (p.Glu110Ter) and c. $-112 \mathrm{C}>\mathrm{G}$ (Table 3). Both mutations have already been reported by our group in another ML III gamma patient, not related to patients A and B. $^{15}$ No pathogenic mutations were detected on the GNPTAB gene.

The nonsense mutation c.328G $>\mathrm{T}$ occurs in exon 6 . The corresponding translation product contains a premature stop codon (p.Glu110Ter) resulting in a predicted truncated protein of 109 amino acids. The mutation c.-112C $>\mathrm{G}$, located at the $5^{\prime}$ untranslated region (UTR), was also not found in 200 control allele samples.

To assess the potential effects of the GNPTG gene mutations at the mRNA level, RT-PCR and cDNA sequence analyses were performed. However, in both patients the normal wild-type GNPTG cDNA sequence was evident with regard to position c.328G $>\mathrm{T}$ (Figure 2). Possible artifactual sample contamination was excluded because (1) the samples were analyzed separately, (2) the primers were designed to specifically amplify the c.328G $>\mathrm{T}$ allele, (3) experimental reproducibility following resampling and reanalysis of the patients and (4) no evidence of contamination was ever detected in negative controls.

To exclude the issue of potential artifactual misincorporation, several further independent experiments were performed employing various different RT-PCR amplification systems to prove the authenticity of the GNPTG alleles and transcripts. Control experiments revealed no evidence of artifactual nucleotide misincorporation in vitro during either PCR or reverse transcription. Finally, BLAST analysis revealed no sequence with homology to the GNPTG gene fragment containing exons 4 to 7 in the human genome.

\section{GNPTG and GNPTAB expression in ML III gamma patients}

The expression of GNPTG mRNA in the fibroblasts of patients A and $B$ were reduced by $99 \%$ in comparison with the mRNA levels in fibroblasts of healthy individuals (Figure 2). In both patients, an increase of 3- and 15-fold (patient A and B, respectively) in GNPTAB levels compared with the median control values was observed.

Presence of wild-type RNA sequence and GNPTG dosage analysis Restriction fragment length polymorphism analysis confirms the presence of both transcripts in patients (data not show), and the GNPTG dosage analysis excluded the possibility of variations in the number of copies in that gene (Figure 3).

\section{DISCUSSION}

In this study, we analyzed the entire coding regions of GNPTG and GNPTAB genes in two ML III gamma patients. Both patients exhibited a mild clinical phenotype and a normal neurological evaluation that is supported by the findings of FIM. Patients A and B presented FIM total scores compatible with complete or modified independence. When we analyzed cognitive and mobility FIM subscores, the patients achieved the maximum score in the FIM cognitive and close to the maximum scores in the FIM mobility. All of these data support previous observations that mutations in the GNPTG gene are predictive of a milder ML III phenotype and a better prognosis than GNPTAB gene mutations, ${ }^{3}$ probably because of the function of each GlcNAc-1-phosphotransferase subunit. The $\alpha$ - and $\beta$-subunits harbor the binding sites for the substrate UDP-GlcNAc, recognize a common protein determinant of lysosomal enzymes and contain the catalytic activity. ${ }^{30,31}$ The function of the $\gamma$-subunit remains to be elucidated, but it has been speculated that it might be involved in the stabilization of $\alpha$ - and $\beta$-subunit conformation that is able to bind lysosomal enzymes efficiently. ${ }^{11,32}$ However, because of the nonsense-mediated mRNA decay (NMD), we did not expect milder phenotypes in patients who are homozygous for nonsense mutations at genes involved in autosomal-recessive diseases.

The difference between the results of gDNA (identification of c.328G $>$ T) and cDNA sequencing (no identification of c.328G $>$ T) could be explained by the following four phenomena. (1) The mRNA editing (c.328G@T). (2) Presence of a pseudogene for GNPTG, but this is not reported in the literature. ${ }^{5}$ (3) Somatic mosaicism. This hypothesis is unlikely because gDNA samples were obtained from more than one cellular type, of both patients, and the results were always congruent, showing only the presence of the mutated allele. However, it could not be excluded as the chromatograms are not sensitive enough to detect faint mosaicism. (4) Presence of copy number variation in GNPTG gene or in exon 6 of the same gene. 
a
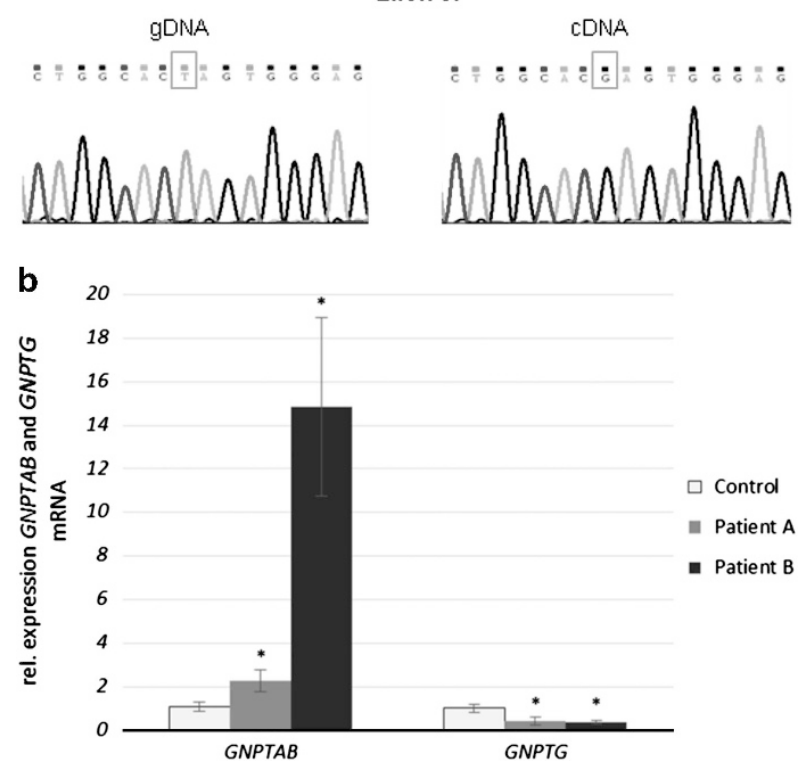

Figure 2 Electropherograms and quantitative mRNA. (a) Electropherograms of genomic DNA (gDNA, abnormal) and complementary DNA (cDNA, normal) for the p.Glu110Ter mutation. (b) GNPTAB and GNPTG expression in mucolipidosis (ML) III gamma patients. The relative levels of GNPTG and GNPTAB mRNA expression were determined in fibroblasts of ML III gamma patients by real-time PCR normalized to GAPDH expression. Analysis of control and ML III patients are the mean of triplicate PCRs obtained from three independent RNA preparations. Data are expressed as the mean fold change in respective gene expression \pm s.d. $\left({ }^{*} P<0.001\right)$. A full color version of this figure is available at the Journal of Human Genetics journal online.

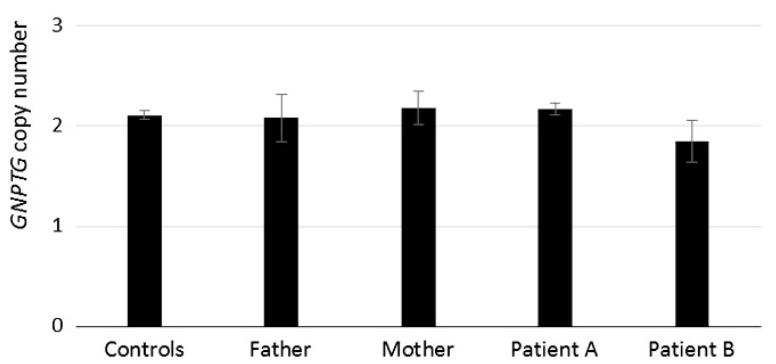

Figure 3 Copy number analysis of GNPTG gene using real-time quantitative PCR (qPCR). This analysis was performed in triplicate using the formula $2 \times 2^{-\Delta \Delta C T} \pm$ s.e.m. The groups are not significantly different (analysis of variance (ANOVA)).

However, the dosage analysis performed herein showed no variations in the number of copies of these regions. Hence, mRNA editing is the most probable explanation for our findings. We point out that although both the wild and the mutant transcripts were identified by restriction fragment length polymorphism in both patients, only the mutant transcript (c.328G $>\mathrm{T}$ ) is target of NMD, and hence we could only sequence the wild fragment.

The mRNA editing could also potentially contribute for the milder phenotype presented by both patients. Recently, a large number of mRNA editing instances in humans have been identified using bioinformatic screens and high-throughput experimental investigations utilizing next-generation sequencing technologies. ${ }^{23,33-37} \mathrm{U}-$ to-G
mRNA editing, which would be required to account for the appearance of wild-type GNPTG mRNA in our patients, has previously been reported to occur in Acanthamoeba castellanii, ${ }^{33}$ human glutamate receptor (GluR7), ${ }^{38}$ PR (PRDI-BF1-RIZ) domain zinc-finger protein $1(P R D M 1)^{39}$ and in mucopolysaccharidosis type II (Hunter Syndrome). ${ }^{16}$ In the DARNED, a database of mRNA editing in humans, more than 100 instances of mRNA editing have been reported in GNPTG, but none are related to ML III gamma. ${ }^{40}$

The nonsense mutation generates premature termination codon; therefore, the observed reduction in GNPTG mRNA levels might be explained by the involvement of the transcripts in the NMD pathway. NMD usually reduces the level of premature termination codonbearing transcripts but does not eliminate them completely. ${ }^{41} \mathrm{NMD}$ has been observed in mucopolisaccharidosis type I, ${ }^{42}$ Niemann-Pick type $\mathrm{C}^{43}$ and ML III gamma. ${ }^{10}$ If the mRNA abundance is reduced because of NMD, it would mean that editing occurs after the pioneer round of translation where NMD usually occurs.

Herein, the $5^{\prime} \mathrm{UTR}$ mutation (c.-112C $>\mathrm{G}$ ) found in cis with the nonsense mutation can also have some effect on the level of transcription of GNPTG. ${ }^{42,44-46}$ Mutations located in the $5^{\prime} \mathrm{UTR}$ may have effects on mRNA expression and, therefore can sometimes be pathogenic. For instance, the presence of $5^{\prime} \mathrm{UTR}$ mutations has been reported as causing TAR (thrombocytopenia with absent radius) syndrome, an autosomal-recessive disease; in patients harboring a previously associated microdeletion in 1q21.1, researchers identified two different low-frequency variants in the regulatory region of $R B M 8 A$. The combination of either variant with the original microdeletion is sufficient to cause this disorder. ${ }^{46}$ Interestingly, the promoter region of GNPTG is overlapped by TSR3 (20S rRNA homolog (Saccharomyces cerevisiae)) gene that is transcribed in the opposite direction as the GNPTG, and hence c.-112C > G can affect the processing of $20 \mathrm{~S}$ rRNAs. $^{21}$

In patients $A$ and $B$, the relative mRNA expression of the gene encoding $\alpha / \beta$-subunit precursor of GlcNAc-1-phosphotransferase (GNPTAB) was found to be upregulated. This upregulated expression suggest that a compensatory mechanism is preventing the complete missorting of newly synthesized lysosomal enzymes. ${ }^{11}$ Patient B has higher levels of GNPTAB than patient A and this may be associated to the less severe clinical phenotype presented by patient $\mathrm{B}$.

Our findings also raises other issues that should be addressed by future studies such as: (1) how does the editing of the c.328 G>T position occur?; (2) does ribosome stalling at the nonsense positions facilitate the editing process?; and (3) does the second mutation we found in the $5^{\prime}$ UTR facilitate the editing?.

In conclusion, we suggest that GNPTG analysis must be performed on gDNA because of the instability of mRNA containing premature stop codons and the occurrence of mRNA editing. The mRNA editing could play an important role in modulating the association between mutant genotype and clinical phenotype.

\section{CONFLICT OF INTEREST}

The authors declare no conflict of interest.

\section{ACKNOWLEDGEMENTS}

We thank the MPS Brasil Network, the Laboratory for Inborn Metabolic Disorders of HCPA, Gabriela Kampf Cury and Osvaldo Alfonso Artigalás for their contributions to this study. We also thank Professor David Bedwell for comments on the paper. This project was supported by Conselho Nacional de Desenvolvimento Científico e Tecnológico (CNPq to RVV.), by Fundação de Amparo à Pesquisa do Rio Grande do Sul (postdoctorate fellowship to FS-L) and by Fundo de Incentivo à Pesquisa e Eventos (FIPE-HCPA). 
1 De Duve, C., Pressman, B., Gianetto, R., Wattiaux, R. \& Appelmans, F. Tissue fractionation studies. 6. Intracellular distribution patterns of enzymes in rat-liver tissue. Biochem. J. 60, 604-617 (1955).

2 Braulke, T. \& Bonifacino, J. S. Sorting of lysosomal proteins. Biochim. Biophys. Acta 1793, 605-614 (2009)

3 Braulke, T., Raas-Rothschild, A. \& Kornfeld, S. I-cell disease and pseudo-Hurler polydystrophy: disorders of lysosomal enzyme phosphorylation and localization. In The Online Metabolic and Molecular Bases of Inherited Disease (eds Val D., Beaudet A., Vogelstein B., Kinzler K., Antonarakis S., Ballabio A., et al.), (The McGraw-Hill Companies, New York, NY, USA, 2013).

4 Raas-Rothschild, A., Cormier-Daire, V., Bao, M., Genin, E., Salomon, R., Brewer, K. et al. Molecular basis of variant pseudo-Hurler polydystrophy (mucolipidosis IIIC). J. Clin. Invest. 105, 673-681 (2000).

5 Tiede, S., Muschol, N., Reutter, G., Cantz, M., Ullrich, K., Braulke, T. et al. Missense mutations in $\mathrm{N}$-acetylglucosamine-1-phosphotransferase alpha/beta subunit gene in a patient with mucolipidosis III and a mild clinical phenotype. Am. J. Med. Genet. A 137A, 235-240 (2005).

6 HGMD. The Human Gene Mutation Database (2015) at http://www.hgmd.cf.ac.uk.

7 Raas-Rothschild, A., Bargal, R., Goldman, O., Ben-Asher, E., Groener, J. E., Toutain, A. et al. Genomic organisation of the UDP-N-acetylglucosamine-1-phosphotransferase gamma subunit (GNPTAG) and its mutations in mucolipidosis III. J. Med. Genet. 41, e52 (2004).

8 Tiede, S., Cantz, M., Raas-Rothschild, A., Muschol, N., Bürger, F., Ullrich, K. et al. A novel mutation in UDP-N-acetylglucosamine-1-phosphotransferase gamma subunit (GNPTAG) in two siblings with mucolipidosis type III alters a used glycosylation site. Hum. Mutat. 24, 535 (2004).

9 Encarnação, M., Lacerda, L., Costa, R., Prata, M. J., Coutinho, M. F., Ribeiro, H. et al. Molecular analysis of the GNPTAB and GNPTG genes in 13 patients with mucolipidosis type II or type III - identification of eight novel mutations. Clin. Genet. 76, 76-84 (2009).

10 Persichetti, E., Chuzhanova, N. A., Dardis, A., Tappino, B., Pohl, S., Thomas, N. S. et al. Identification and molecular characterization of six novel mutations in the UDP-N-acetylglucosamine-1-phosphotransferase gamma subunit (GNPTG) gene in patients with mucolipidosis III gamma. Hum. Mutat. 30, 978-984 (2009).

11 Pohl, S., Tiede, S., Castrichini, M., Cantz, M., Gieselmann, V., Braulke, T. et al. Compensatory expression of human $\mathrm{N}$-acetylglucosaminyl-1-phosphotransferase subunits in mucolipidosis type III gamma. Biochim. Biophys. Acta 1792, 221-225 (2009).

12 Zarghooni, M. \& Dittakavi, S. S. R. Molecular analysis of cell lines from patients with mucolipidosis II and mucolipidosis III. Am. J. Med. Genet A 149A, 2753-2761 (2009).

13 Gao, Y., Yang, K., Xu, S., Wang, C., Liu, J., Zhang, Z. et al. Identification of compound heterozygous mutations in GNPTG in three siblings of a Chinese family with mucolipidosis type III gamma. Mol. Genet. Metab. 102, 107-109 (2011).

14 Liu, S., Zhang, W., Shi, H., Meng, Y. \& Qiu, Z. Three novel homozygous mutations in the GNPTG gene that cause mucolipidosis type III gamma. Gene 535, 294-298 (2014).

15 Velho, R. V., Alegra, T., Sperb, F., Ludwig, N. F., Saraiva-Pereira, M. L., Matte, U. et al. A de novo or germline mutation in a family with Mucolipidosis III gamma: implications for molecular diagnosis and genetic counseling. Mol. Genet. Metab. Rep. 1, 98-102 (2014).

16 Lualdi, S., Tappino, B., Di Duca, M., Dardis, A., Anderson, C. J., Biassoni, R. et al. Enigmatic In Vivo iduronate-2-sulfatase (IDS) mutant transcript correction to wild-type in Hunter syndrome. Hum. Mutat. 31, E1261-E1285 (2010).

17 Peters, C. \& Steward, C. G. Hematopoietic cell transplantation for inherited metabolic diseases: an overview of outcomes and practice guidelines. Bone Marrow Transplant. 31, 229-239 (2003).

18 Buratowski, S. Transcription gene expression-where to start? Science $\mathbf{3 2 2}$, 1804-1805 (2008).

19 Preker, P., Lacerda, L., Costa, R., Prata, M. J., Coutinho, M. F., Ribeiro, H. et al. RNA exosome depletion reveals transcription upstream of active human promoters. Science 322, 1851-1854 (2008).

20 Trapnell, C., Hendrickson, D. G., Sauvageau, M., Goff, L., Rinn, J. L. \& Pachter, L. Differential analysis of gene regulation at transcript resolution with RNA-seq. Nat. Biotechnol. 31, 46-53 (2013).

21 Li, Z., Lee, I., Moradi, E., Hung, N. J., Johnson, A. W. \& Marcotte, E. M. Rational extension of the ribosome biogenesis pathway using network-guided genetics. PLoS Biol. 7, e1000213 (2009).
22 Benne, R., Van den Burg, J., Brakenhoff, J. P., Sloof, P., Van Boom, J. H. \& Tromp, M. C. Major transcript of the frameshifted coxll gene from trypanosome mitochondria contains four nucleotides that are not encoded in the DNA. Cell 46, 819-826 (1986).

23 Farajollahi, S. \& Maas, S. Molecular diversity through RNA editing: a balancing act. Trends Genet. 26, 221-230 (2010).

24 Riberto, M., Miyazaki, M. H., Jucá, S. S. H., Sakamoto, H. \& Potiguara, P. Validação da Versão Brasileira da Medida de Independência Funcional [Validation of the Brazilian version of Functional Independence Measure]. Acta Fisiátrica 11 72-76 (2004).

25 Mancini, M. C. \& Mello, M. A. F. in Terapia ocupacional fundamentação e prática (eds Cavalcanti, A. \& Galvão, C.) 49-54 (Guanabara Koogan, Rio de Janeiro, Brazil, 2007).

26 Gajdosik, R. L. \& Bohannon, R. W. Clinical measurement of range of motion. Review of goniometry emphasizing reliability and validity. Phys. Ther. 67, 1867-1872 (1987).

27 Cury, G. K., Matte, U., Artigalás, O., Alegra, T., Velho, R. V., Sperb, F. et al. Mucolipidosis II and III alpha/beta in Brazil: analysis of the GNPTAB gene. Gene 524, 59-64 (2013).

28 Ho, C. Y. S., Tang, N. L., Yeung, A. K., Lau, A. K., Hui, J., Lo, A. W. et al. Abnormal expressions of the subunits of the UDP-N-acetylglucosamine: lysosomal enzyme, $\mathrm{N}$-acetylglucosamine-1-phosphotransferase, result in the formation of cytoplasmic vacuoles resembling those of the I-cells. J. Mol. Med. (Berl.) 85, 351-360 (2007).

29 Szantai, E., Elek, Z., Guttman, A. \& Sasvari-Szekely, M. Candidate gene copy number analysis by PCR and multicapillary electrophoresis. Electrophoresis 30, 1098-1101 (2009).

30 Braulke, T., Pohl, S. \& Storch, S. Molecular analysis of the GlcNac-1phosphotransferase. J. Inherit. Metab. Dis. 31, 253-257 (2008).

31 Qian, Y., Lee, I., Lee, W. S., Qian, M., Kudo, M., Canfield, W. M. et al. Functions of the alpha, beta, and gamma subunits of UDP-GIcNAc:lysosomal enzyme $\mathrm{N}$-acetylglucosamine-1-phosphotransferase. J. Biol. Chem. 285, 3360-3370 (2010).

32 Lee, W.-S., Payne, B. J., Gelfman, C. M., Vogel, P. \& Kornfeld, S. Murine UDP-GlcNAc: lysosomal enzyme $\mathrm{N}$-acetylglucosamine-1-phosphotransferase lacking the gammasubunit retains substantial activity toward acid hydrolases. J. Biol. Chem. 282, 27198-27203 (2007).

33 Brennicke, A, Marchfelder, A. \& Binder, S. RNA editing. FEMS Microbiol. Rev. 23, 297-316 (1999).

34 Knoop, V. When you can't trust the DNA: RNA editing changes transcript sequences. Cell. Mol. Life Sci. 68, 567-586 (2011).

35 Peng, Z., Cheng, Y., Tan, B. C., Kang, L., Tian, Z., Zhu, Y. et al. Comprehensive analysis of RNA-Seq data reveals extensive RNA editing in a human transcriptome. Nat. Biotechnol. 30, 253-260 (2012).

36 Ramaswami, G., Zhang, R., Piskol, R., Keegan, L. P., Deng, P., O'Connell, M. A. et al. Identifying RNA editing sites using RNA sequencing data alone. Nat. Methods 10, 128-132 (2013).

37 Ramaswami, G. \& Li, J. B. RADAR: a rigorously annotated database of A-to-I RNA editing. Nucleic Acids Res. 42, D109-D113 (2014).

38 Novo, F. J., Kruszewski, A., MacDermot, K. D., Goldspink, G. \& Górecki, D. C. Editing of human alpha-galactosidase RNA resulting in a pyrimidine to purine conversion. Nucleic Acids Res. 23, 2636-2640 (1995).

39 Tam, W., Gomez, M., Chadburn, A., Lee, J. W., Chan, W. C., Knowles, D. M. et al. Mutational analysis of PRDM1 indicates a tumor-suppressor role in diffuse large B-cell lymphomas. Blood 107, 4090-4100 (2006).

40 Kiran, A. \& Baranov, P. V. DARNED: a DAtabase of RNa EDiting in humans. Bioinformatics 26, 1772-1776 (2010).

41 Linde, L. \& Kerem, B. Introducing sense into nonsense in treatments of human genetic diseases. Trends Genet. 24, 552-563 (2008).

42 Almeida, A. C. G., Pasqualim, G., Mayer, F. Q., Schwartz, I. V., Souza, C. F., Giugliani, R. et al. Analysis of cDNA molecules is not suitable for the molecular diagnosis of Mucopolysaccharidosis type I. Diagn. Mol. Pathol. 21, 53-55 (2012).

43 Macías-Vidal, J., Gort, L., Lluch, M., Pineda, M. \& Coll, M. J. Nonsense-mediated mRNA decay process in nine alleles of Niemann-Pick type $C$ patients from Spain. Mol. Genet. Metab. 97, 60-64 (2009).

44 Rebbapragada, I. \& Lykke-Andersen, J. Execution of nonsense-mediated mRNA decay: what defines a substrate? Curr. Opin. Cell Biol. 21, 394-402 (2009).

45 Bhuvanagiri, M., Schlitter, A. M., Hentze, M. W. \& Kulozik, A. E. NMD: RNA biology meets human genetic medicine. Biochem. J. 430, 365-377 (2010).

46 Albers, C. A., Paul, D. S., Schulze, H., Freson, K., Stephens, J. C., Smethurst, P. A. et al. Compound inheritance of a low-frequency regulatory SNP and a rare null mutation in exon-junction complex subunit RBM8A causes TAR syndrome. Nat. Genet. 44, S1-S2 (2012). 